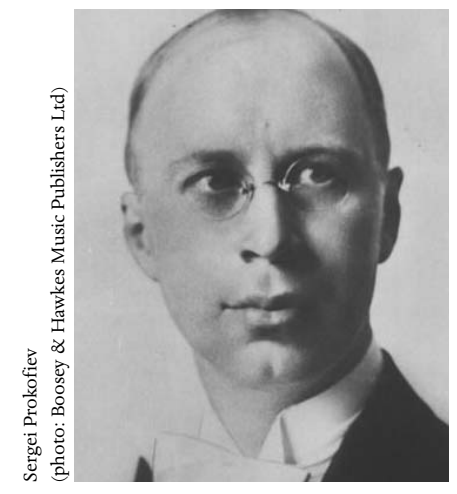

\title{
AMBIGUOUS MODERNISM: THE EARLY ORCHESTRAL WORKS OF SERGEI PROKOFIEV
}

\author{
Christina K Guillaumier
}

Sergei Prokofiev's association with modernism was a curious one: on the one hand, he thought his technically innovative, bold and challenging music positioned him as a modernist but on the other, he remained wary of aligning himself with any specific movement. Such a combination of reluctance and ambiguity in the face of a movement that was engaging interwar Europe with such intensity stems from what can be viewed as an overly protective attitude to his own purity of idiom. Prokofiev was keenly aware of his own prodigious talent and simultaneously anxious of possible musical influence. Nonetheless, he continued to be watchful of cutting-edge developments in music even if he was not particularly sympathetic to the accompanying philosophical debates on modern music.

While definitions of modernism in music are as numerous as they are disparate, it has generally been agreed that modern music invokes a radical compositional aesthetic, employs complex technical experimentation while remaining essentially self-reflexive. Daniel Albright indeed goes as far as proposing that technical innovation may be the sole foundation of modernism when he suggests that 'where there is technical aggressiveness, there is Modernism'. 'Technical aggressiveness' was an issue that Prokofiev knew a great deal about. He graduated from the St Petersburg Conservatory in 1914 having gained an enfant terrible reputation: he was a powerful pianist with a personality to match and possessed of superb technical capabilities. By the time Prokofiev came to graduate, he had a large repertoire of music written for his instrument. His music displayed a skepticism of tradition that earned him the image of an iconoclast and made him a favourite with the St Petersburg avant-garde. He built his reputation as a modernist through the Evenings of Contemporary Music ${ }^{2}$ where he frequently appeared in the dual role of composer-pianist. Here, Prokofiev's music was heard by key figures of the St Petersburg cultural scene: Alfred Nurok, Walter

\footnotetext{
1 Daniel Albright, ed. Modernism and Music: An Anthology of Sources (Chicago and London: The University of Chicago Press, 2004), p. 11.

2 The Evenings of Contemporary Music was the precursor of the Association of Contemporary Music (ACM): it came into existence in 1901 and was disbanded in 1912. The Society had some connexions with Diaghilev's Mir Iskusstva. A hotbed of contemporary music, the Society also invited composers from abroad to their musical soirées, where music by Schoenberg, Mahler, Strauss, Debussy and Ravel, among others, was performed. The evenings also supported local talent, however, and Prokofiev's early music was played alongside that of Stravinsky and Miaskovsky. Prokofiev's introduction to the Society must have played an important part in widening his knowledge of modernist repertoire, although he himself never elaborates on this in any detail in his writing. Prokofiev was invited to play for the organizing committee of Evenings of Contemporary Music in February 1908.
} 
Nouvel, Alexander Medem and Vladimir Senilov among others. ${ }^{3}$ Such an introduction to the avant-garde world of St Petersburg would prove to be invaluable, marking the beginning of Prokofiev's foray into the contemporary musical world and opening him up to the cultural influences, both musical and otherwise of St Petersburg. ${ }^{4}$ Alfred Nurok and Walter Nouvel would continue to champion his music as being the prime example of contemporary Russian modernism. So would the critic Vladimir Karatygin. Their support of the young Prokofiev would do much to launch his image as enfant terrible and upcoming modernist composer, an image that came to define Prokofiev's performances.

Crucially, the pieces that Prokofiev performed at the Evenings of Contemporary Music consisted almost exclusively of his own early works for piano such as Sarcasms op. 17 and the Four Études op 2. These are complex and dissonant works which tested the limits of piano technique and which never failed to draw attention to his own formidable technique when he played them in public. (We will return to discuss the effect of these works in the next section). Conversely, contemporary orchestral works belonged to an entirely different soundscape. These included The White Swan and Wave, ${ }^{5}$ two female choruses with orchestra set to Balmont's words, featuring lush harmonies, smooth textures, and an orchestration devoid of the typical Prokofievan brass section. The difference between the works for piano and other early works such as the work for small orchestra entitled Autumnal Sketch, op. 8 and the symphonic tableau Dreams, op. 6 is tremendous. ${ }^{6}$ It is almost unimaginable that such contrasting works were written by the same composer.

A stylistic and technical gap thus existed between Prokofiev's modernist writing for his instrument and contemporary writing for orchestra. The lyrical lines that occur in Dreams and Autumnal Sketch are but a faint preview of the long-limbed melodic ideas that would characterize later orchestral writing. ${ }^{7}$ The harmony in these early works for orchestra suggests that Prokofiev had not outgrown Straussian, Wagnerian and Scriabinesque influences. The sumptuous orchestration and chromatic harmony of Autumnal Sketch is in direct contrast to the biting sonorities, unexpected cadences and dissonant harmonies that occur in the piano works of the post-Conservatory phase.

\footnotetext{
3 The first two were music critics and writers who had ties to Mir Isskustva and Sergei Diaghilev. Richard Taruskin describes Nurok as the 'spiritus rector' of the organization and a 'highly cultivated musical dilettante'. (Richard Taruskin, Stravinsky and the Russian traditions: a biography of the works through Mavra Oxford: Oxford University Press, 1996), p. 372. Medem was a pianist, composer and professor at the St Petersburg Conservatory. Vladimir Senilov was a minor composer. Among his works was a symphonic poem entitled The Scythians (1912).

${ }^{4}$ Such influences are discussed at greater length in Suzanne Moisson-Frankhauser's Serge Prokofiev et les courants esthéthiques de son temps (1891-1953) (Paris: Publications orientalistes de France, c. 1974).

5 The White Swan and Wave are published as Two Choral Songs op. 7 and were composed between 1909 and 1910

${ }^{6}$ While such a stylistic gap often occurred in the works of other composers (such as Bartók) who used the piano as a compositional stimulus, the case of Prokofiev is, I think, quite unique. His early development as a precocious composer (his first composition was written at the age of five) led to his developing a personal musical idiom based on various gestures and compositional strategies first explored in these early works. Among the early unpublished works of the young Prokofiev are around 60 pieces written for solo piano entitled Little Songs. These works display the embryonic origins of Prokofiev's compositional style. Among the gestures that remained important to Prokofiev are the repeated note, the use of chromaticism for colour and effect, several types of driving bass lines and lyrical melodytypes. Many of these musical ideas would remain compositional staples even as he attained compositional maturity.

7 Both of these works were composed in 1910. Prokofiev was to revise Autumnal Sketch in
} 1915 and 1934. 
In a 1918 interview, Prokofiev himself notes the lacuna in his compositional technique. 'When I first left the Conservatory', he tells Frederich H. Martens, 'I had so many ideas, and not enough technic to express them as I wished' ${ }^{8}$ Was the reason behind these entirely different sound-worlds simply a result of inadequate orchestral technique? Or could it be that Prokofiev's thoughts, like those of so many other composer-pianists, had become so intertwined with the piano's shape and geography that he was unable to extricate the musical ideas from their pianistic forms? The piano works demonstrate that Prokofiev's compositional technique for his instrument was advanced; his progress in that area was doubtlessly propelled forward by his own colossal pianistic technique. His early compositions for piano were works that he composed for himself to play: he clearly inscribed his own performing self into the piano compositions, these works thus bear the imprint of what Stravinsky would call 'biological personality'. ${ }^{9}$ The need to imprint his music with a distinctive individuality was a driving force of Prokofiev's compositional aesthetic: throughout his career he continued to emphasize the importance of developing and maintaining a unique compositional voice.

As a composer for piano, Prokofiev may have achieved musical maturity at a precociously early age: these works marked him out and defined him as a modernist. But writing in a similarly modernist vein for the orchestral medium did not come easily to him. It took Prokofiev years of what he termed 'unremitting struggle' before he was to realize his own 'salvation in composition' as he saw it. ${ }^{10}$ But even then, such 'salvation' was not unequivocal: the self-doubts that accompanied the composition of his arch-modernist Second Symphony were yet to come. ${ }^{11}$ The works discussed below were composed during a critical period of self-examination, when Prokofiev was struggling to create a personal orchestral voice to match the one he had so successfully forged in his writings for the piano. The Scythian Suite and Seven, They Are Seven mark a defining phase in Prokofiev's orchestral writing. These works are Prokofiev's earliest modernist statement for orchestral forces and in many ways mark the beginning of his bridging of the gap between his compositional technique for piano and that for orchestra.

In these works, Prokofiev makes use of modernist musical techniques which include repetition and musical looping, a dialectic between sound and silence, the use of shock tactics and attention-grabbing gestures, developmental strategies based on thematic conflict and collision, pulsating and motoric rhythms, disruptive musical gestures, abrupt changes of direction. Many of these gestures were developed and refined in Prokofiev's output for the piano: these were then used to modernize his orchestral writing. The works discussed here demonstrate aspects of compositional processes that Prokofiev would come to refine. They also show Prokofiev relying on his already mature harmonic vocabulary and sound-palette for the piano to inspire his orchestral

\footnotetext{
8 Frederick H. Martens, 'The Last Word in Russian Music: An Interview with Serge Prokofiev', The Musical Observer, November 1918.

${ }^{9}$ Igor Stravinsky and Robert Craft, Memories and Commentaries (London: Faber \& Faber, 1960), p. 67. In doing so, Prokofiev was highlighting 'the direct relationship between the work of art and its creator', which, for the cultural historian Robin Walz was a key quality of modernist art. See Robin Walz, Modernism (Harlow, England: Pearson Longman), p. 11.

${ }^{10}$ Frederick H. Martens, 'The Last Word in Russian Music: An Interview with Serge Prokofiev', The Musical Observer, November 1918.

${ }^{11}$ Symphony No. 2, op. 40 in D minor was completed in 1924 and was to shake Prokofiev's notorious self-confidence. He would later declare it to be a work he barely understood himself. It was to be his last experiment in such an overtly self-conscious modernist vein.
} 
writing. Ultimately these works trace the path he took as he tried to reconcile and transfer his forward harmonic thinking and specific gestural language developed in his writing for the piano into his orchestral idiom.

\section{Reception in the West}

Prokofiev's trip to America in 1918 cemented his early reputation as a modernist. According to the New York Herald, the composer was introduced to American audiences as a representative of the ultra modern revolutionary and even incendiary Russian composers best represented, as perhaps best known, by Stravinsky and all his works'. ${ }^{12}$ The comparison with Stravinsky would probably have irked Prokofiev, who, above all, desired to be considered original and unique, but it certainly did him no harm in terms of enhancing his reputation as a modernist composer. Together with Stravinsky and Ornstein, American critics saw Prokofiev as a modernist composer and different from the 'classic' Rachmaninov. He was described as a 'bold and bad young man'. ${ }^{13} \mathrm{His}$ incredible prowess as a pianist as well as the 'personal magnetism, intensity, power and verve in his playing' overwhelmed the audience but his compositions were ironically (since as a composer Prokofiev aimed for clarity and transparent textures in his compositions, particularly in his piano works) labelled as 'formless and impressionist vapourings'. His Four Études, for example, appeared 'decidedly vague in form and melody, effective from their force and original rhythms rather than their intrinsic musical value'. ${ }^{14}$

Perhaps the most influential and lasting image from this first American tour was that of Prokofiev as a Bolshevisk pianist: 'His fingers are steel, his wrists steel, his biceps and triceps steel, his scapula steel. He is a tonal steel thrust'. ${ }^{15}$ Prokofiev's music also espoused the Futurist's central image of speed, as his performance took double notes, octaves and chords 'at a dizzying tempo' 16 and his writing featured toccata-like figures and ostinato rhythms. This much-mythologized image of Prokofiev as a Bolshevik musician was of course nothing more than a Western construct: it was, however, to remain the enduring image of Prokofiev's piano playing throughout his career. His early piano works such as the Sarcasms op. 17, the Etudes op. 2 and the Toccata op. 11, all composed between 1909 and 1914, consolidated the image of Prokofiev as a modernist: they also colour our understanding of his later works and shifts of style. As a performer, then, Prokofiev was a modernist through and through; as a composer, his modernism is somewhat more ambiguous.

Despite Prokofiev's early modernist reputation, the music itself plays out a dialogue between tradition and innovation. This dialectic between the old and the new made his reception in Europe problematic, but the dissonant quality of his music would ultimately endear him to the modernists. In the same 1918 interview he gave to The Musical Observer, Prokofiev described dissonance as 'the combination of movements of sound in quantity which are more complex than consonant combinations. As a result it is more difficult for the ear to seize and follow them; yet, once grasped, they afford a richer and more subtle appreciation than

\footnotetext{
${ }^{12}$ New York Herald, 2 November 1918

${ }_{13}$ New York Times, 15 June 1924.

${ }^{14}$ New York Herald, 2 November 1918.

${ }^{15}$ New York Herald, 2 November 1918

${ }_{16}$ New York Herald, 2 November 1918.
} 
simpler harmonies can give'. ${ }^{17}$ Prokofiev saw dissonance as a form of aural complexity, as a way of engaging the listeners and drawing them into the deciphering process. His music defamiliarizes sound combinations we are used to, with the ultimate aim of engaging his audience: context makes his dissonance particularly effective. The interplay between sounds that are heard and sounds that are aurally imagined is a crucial feature of Prokofiev's writing.

\section{Ala and Lolli}

The Scythian Suite originated in the ballet Ala and Lolli-centered around the abduction of the goddess Ala who is eventually saved by the mortal hero Lolli. Despite the possibilities such an exotic scenario might suggest, especially within the context of Diaghilev's Ballets Russes seasons in Paris, Prokofiev's first sketch for the ballet Ala and Lolli did not meet with the impresario's approval. When Diaghilev commissioned Prokofiev to work with the poet Sergey Gorodetsky, ${ }^{18}$ he may have been hoping for another Stravinskian succèss de scandale. The relationship between Gorodetsky and Prokofiev got off to a rather shaky start: scheduling the initial meeting turned out to be difficult and it was not until four months later that the two finally met to discuss the scenario. Gorodetsky was initially not forthcoming with ideas, an attitude that frustrated Prokofiev and led to his nicknaming the poet a 'lazybones'. ${ }^{19}$ At their first meeting Prokofiev was annoyed to find that the scenario 'had been merely sketched out, not finished, and was quite insubstantial as regards to content' ${ }^{20}$ In these initial discussions with Gorodetsky, Prokofiev determined that the scenario would be 'drawn from Russian life', 'either dramatic or comic but not just neutral', 'dense and complex with rapid development of the action', 'there should not be any moments without action on stage', 'it should consist of five or six short scenes and last in total about half an hour'. ${ }^{21}$

In correspondence with his lifelong friend, the composer Nikolai Miaskovsky, Prokofiev notes that in the ballet he indulged his penchant for 'orchestral tone-painting' and during its composition he took 'pleasure in every kind of instrumental combination'. ${ }^{22}$ Nonetheless, despite Prokofiev's enjoyment of the compositional process, Diaghilev was not impressed. Two months later, Prokofiev was writing to his mother that Diaghilev made several 'fundamental changes to the subject' even before he had heard the music. Because the original score of Ala and Lolli is lost to us, there is no way to verify the full extent of Prokofiev's compositional revisions and to determine the extent to which Diaghilev shaped the composer's musical thoughts. ${ }^{23}$ Our discussion can only be based on the Scythian Suite. Nonetheless, Prokofiev's assistant Michel Astrov notes that even though the decision to write Ala and Lolli as a

${ }^{17}$ Frederick H. Martens, 'The Last Word in Russian Music: An Interview with Serge Prokofiev', The Musical Observer, November 1918.

${ }_{18}$ The Russian poet Sergey Gorodetsky (1884-1967), together with Nikolay Gumilyov, was the founder of the movement known as Acmeism. Diaghilev suggested that he work with Prokofiev on the libretto for the ballet Ala and Lolli.

${ }^{19}$ Sergey Prokofiev, Diaries 1907-1914: Prodigious Youth trans. Anthony Phillips (London: Faber and Faber, 2006), p. 787. Hereafter cited as Diaries Vol. 1.

${ }^{20}$ Diaries, Vol. 1, p.753. Prokofiev outlines the five-scene scenario in his entry for 9 October 1914.

${ }^{21}$ Diaries, Vol. 1, p.716.

22 S.S. Prokofiev i N. Ya Myaskovsky: Perepiska Miralda Kozlova and Nina Yatsenko eds. (Moscow: Sovietsky Kompozitor, 1977), p. 129. Letter dated 12 December 1914.

${ }^{23}$ Stephen D. Press provides an insightful musical analysis of the ballets Prokofiev wrote for Diaghilev as well as an evaluation of the composer's balletic style of the period in his Prokofiev's Ballets for Diaghilev (Aldershot, England: Ashgate, 2006). 
ballet was abandoned, the music for the most pivotal moments of the narrative was included in the suite. ${ }^{24}$ Diary entries for the period reveal that when Diaghilev heard the music he considered it to be international music'. 'What on earth are you, a Russian composer with a Russian theme, thinking of, writing international music?' he demanded of Prokofiev. ${ }^{25}$ Diaghilev convinced the composer to rewrite and cut the music and to completely revise the subject. Surprisingly, Prokofiev agreed to this idea immediately: he was persuaded to write 'music that was national in character'.

One wonders whether Prokofiev ever fully understood Diaghilev's brief. The impresario convinced him to write a work based on a Russian fable and urged him to write music that would 'unequivocally be grotesque, grotesque and grotesque, with none of those pompous sagas about Wagnerian heroes, please'. ${ }^{26}$ And so, having convinced Prokofiev that he needed to choose a completely different subject and to entirely re-write the score, Diaghilev and his wayward protégé waited for Stravinsky and his enormous collection of Russian fairytales. Eventually, they both settled on a tale about a clown, which would become the ballet Chout. No further mention of Ala and Lolli was made by Diaghilev. ${ }^{27}$ But Prokofiev was loath to give up on a work over which he had lavished so much effort and in June of 1915 turned to Ala and Lolli with the intention of creating a suite out of its material. Intriguingly, this time round, the orchestration process proved to be 'dreadfully difficult [...], but more satisfying that I had anticipated'.

Prokofiev had approached the composition of the ballet through images, thus creating a network of imagery whose balletic origins remain very palpable in Scythian Suite. In the compositional processes of Ala and Lolli, the visual imagery is deployed to generate narrative. This was not the first time that Prokofiev would find visual images to be an important compositional inspiration; it would remain a compositional constant. ${ }^{28}$ Prokofiev's structural notes for the ballet reveal the way imagery was used to forge the work's form: he envisions the form of Ala's dance in four parts, each of which corresponds to a specific mood: 'an outpouring of joy at her liberation'; 'a kind of mystical rite'; 'a slightly affected gratitude'; 'a joyful dance'. For Scene 3 Prokofiev composed music 'for the horrid creatures who were dragging Ala with them' ${ }^{29}$ and in his approach to Scene 4 he notes that he conceived of it 'not as a manifestation of nature but as a procession of the forces of heaven, culminating in the appearance of the Sun God himself' ${ }^{30}$ Throughout the composition of his work, Prokofiev continues to use imagery as the basis of his compositional structure.

\footnotetext{
${ }^{24}$ Unpublished letter from Michel Astrov (Prokofiev's secretary at the time) to Dr Hedwig Kraus, dated 5 December 1932. Serge Prokofiev Archives, XXXII-21.

25 Sergey Prokofiev, Diaries 1915-1923: Behind the Mask trans. Anthony Phillips (London: Faber and Faber, 2008), p. 22. Henceforth cited as Diaries, Vol. 2. It is possible that the first musica drafts of Ala and Lolli shared a similar style to Autumnal Sketch and Dreams, both works that bear traces of the influence of Scriabin and Strauss, hence Diaghilev's reference to 'international music'

${ }^{26}$ Diaries, Vol. 2, p.24.

27 Prokofiev and Diaghilev devised the scenario for Chout in March 1915 and the composer began making sketches for the ballet in May of the same year.

28 Because this is a ballet, it is perhaps unsurprising that Prokofiev would find visual images to be an important stimulus. In his operas The Gambler and Fiery Angel Prokofiev would use spe cific images to generate the thematic material of particular scenes. The composer's ability to think visually is described by Sergei Eisenstein, with whom Prokofiev worked on Alexander Nevsky and Ivan the Terrible. See the chapter entitled 'Form and Content - Practice' in Sergei Eisenstein, The Film Sense, trans. J. Leyda (San Diego: Harcourt Brace, 1947), pp. 157-216.

${ }^{29}$ Diaries, Vol. 1, p.777.

${ }^{30}$ Diaries, Vol. 1, p.767.
} 
Ala and Lolli demonstrates Prokofiev's modernist compositional techniques. Here we find a reconfiguration of sound through the use of disruptive gestures; juxtaposed layers of sound; pulsating rhythms; creation of specific aural imagery; ostinatos; obliteration of tonality; harmony that is in a dialectic engagement with absent sounds; economical use of language and 'effect' tactics. Commentators have often noted Prokofiev's indebtedness to Stravinsky's Rite of Spring in this work. The composer himself claims that he had not understood Stravinsky's work but that it was 'quite possible that I was also searching for the same images in my own way'. ${ }^{31}$ Prokofiev's ballet also makes reference to Russian musical traditions. The work makes use of fairy-tale, magical imagery, which had already appeared in Prokofiev's piano writing. ${ }^{32}$ It is also impossible to ignore Prokofiev's debt to Rimsky Korsakov's imagery in specific parts of Ala and Lolli. In the first movement of the suite, L'adoration de Vélèss et de Ala, the Poco Più Lento section draws on this fairy-tale imagery: the chosen instrumentation of three flutes, celesta, harp, piano, violas and cellos enhances the ethereal sound of the passage; the chromatic murmurs on the violas and the gradual addition of the muted higher strings, the winding woodwind lines and continuous phrases suggest a suspension of harmony and of musical time.

Like Rimsky-Korsakov, Prokofiev makes use of artifice and 'effect' tactics which feature prominently in the full orchestration of Adoration. Trills are played by the entire woodwind section and percussion, glissandos on harps and piano, and the insistent repeated-note gesture is played in the high flute registers. The scoring of Ala and Lolli is opulent: the woodwind requires three of each kind and the brass section is enhanced to include five trumpets, eight horns, four trombones. The composer thus had a full gamut of colouring at his disposal which he manipulated with great effect in Scythian Suite.

Prokofiev's writing is also economical, a trait which is particularly evident at figure 8 (see Example 1) where the entire section is built on the elements of the tritone; the semitone shift; and chromatic scalar figurations used for 'effect'. These are repeated and transformed into ostinatos. Prokofiev's ability to work with isolated gestures and forge a narrative out of these very separate materials positions him as a modernist technician. The descending flute motif and its accompanying muted soundscape is sustained across 21 bars before the texture is expanded: the hypnotic effect of this flute figuration is almost Debussian, but the dream-like effect is countered by the tritone embedded in the celesta part and by the harmonies of the harp part. These harmonies outline the dialectic between sounded and absent harmonies (which we aurally reconstruct). The two main chords played by the harps are built on thirds: $G_{b}-B_{b}-F_{b}$ and $A b-C-G b$. The roots of these chords are a tone apart and each chord combination is missing the 5 th, further enhancing the hollow texture. The neighbouring chords create a kind of musical undulation that has a hypnotic effect. At first the listener is drawn in, aurally trying to fill in the absent harmonies; the repetition, however, has quite the opposite effect - gradually we accept these alternating chords as our harmonic key-stones.

\footnotetext{
31 'Autobiography' in Sergei Prokofiev: Soviet Diary 1927 and other writings trans. and ed. Oleg Prokofiev (London and Boston: Faber and Faber 1991), p. 250.

32 Boris Berman draws attantion to examples of this imagery in the piano sonatas. See Prokofiev's Piano Sonatas (New Haven and London: Yale University Press, 2008).
} 

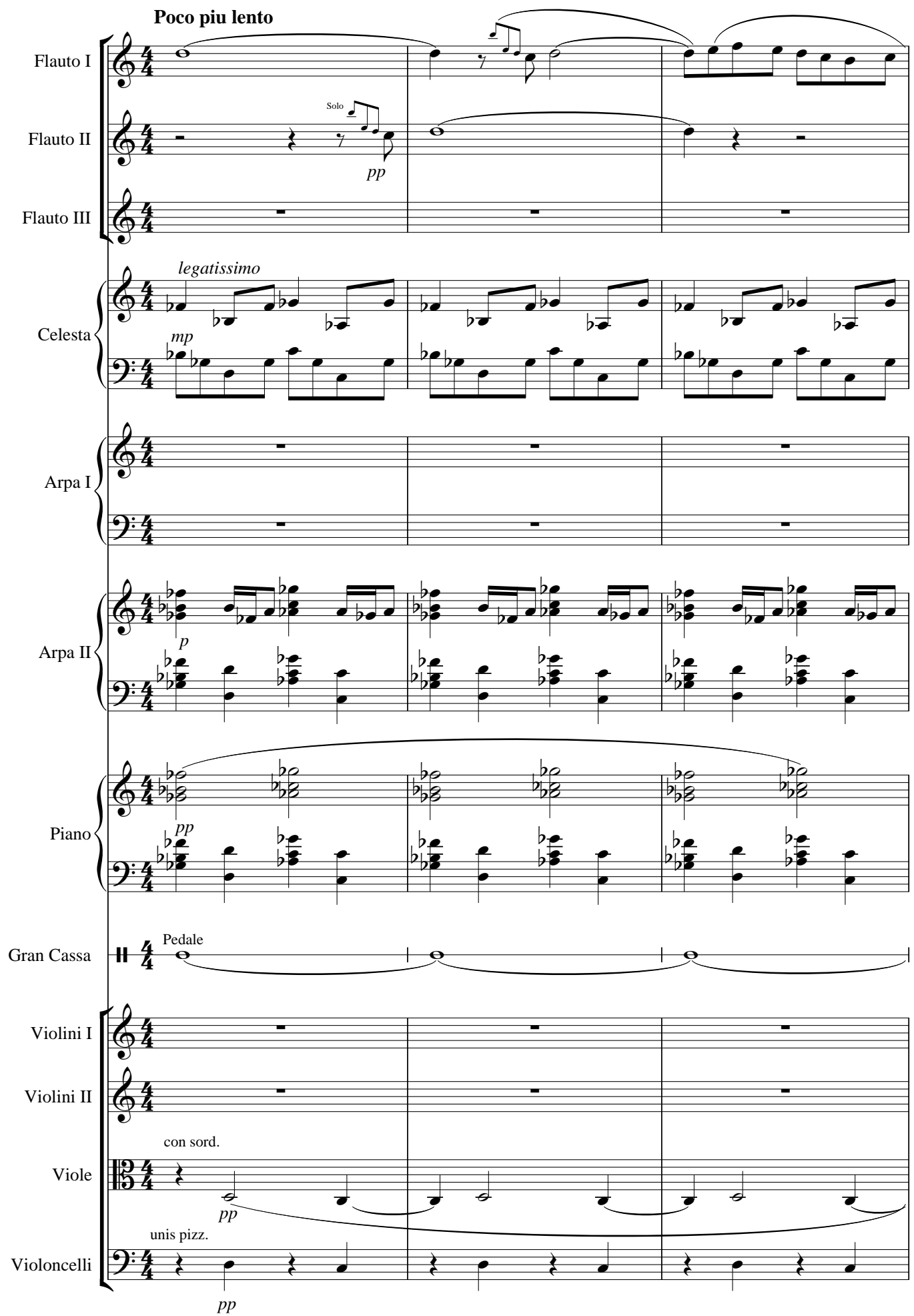


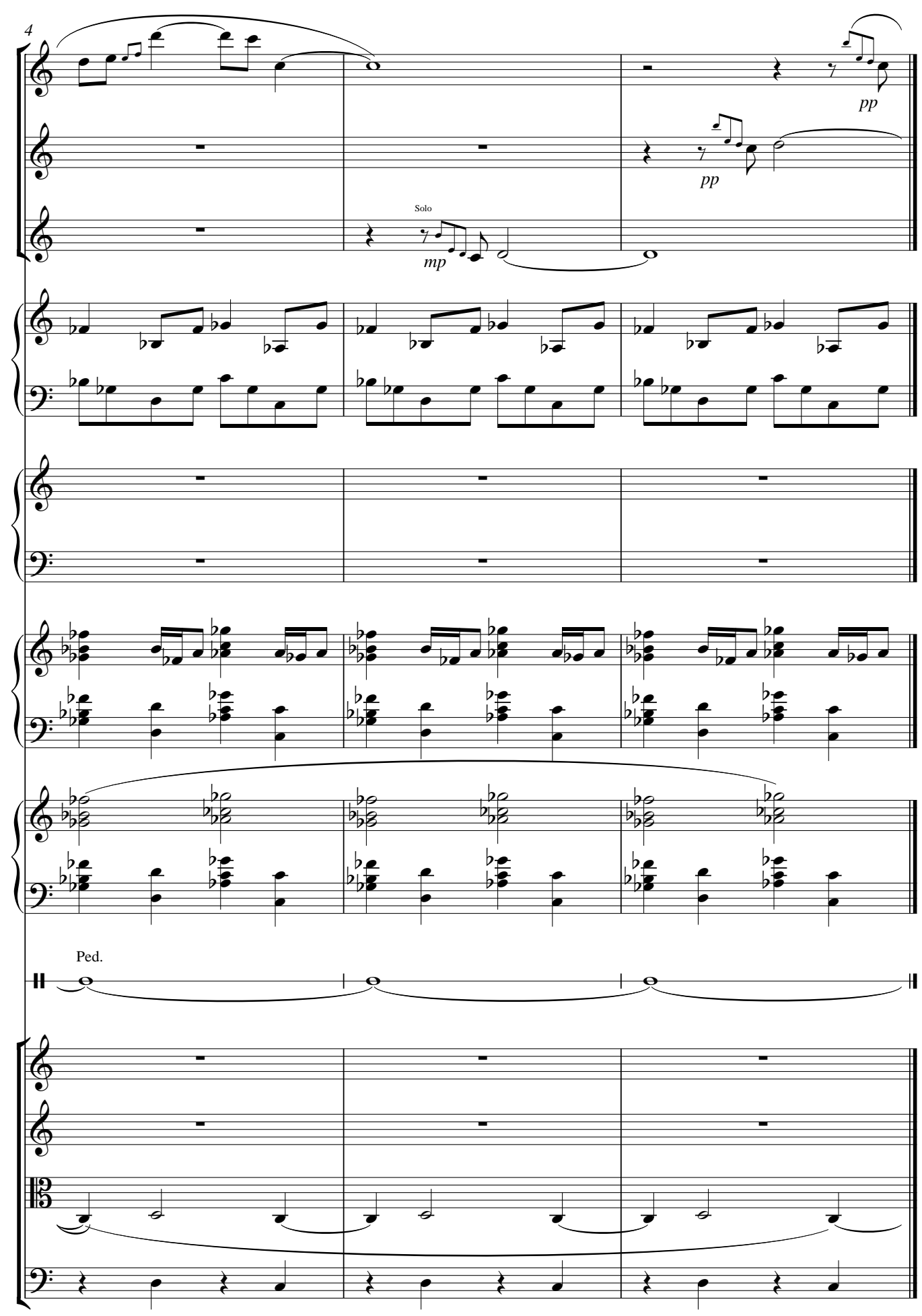


Prokofiev's penchant for cinematic techniques can be heard at figure 7 where the fade-out method is used to signal the end of a section and to herald the beginning of the next. The section is based on a repeated chordal figure based on thirds against a repeated note on pitch class $\mathrm{C}$, which functions as a 'pseudo-tonic' ${ }^{33}$ An accompaniment of rocking quavers, outlining a German 6th, maintains momentum. At other times the use of dissonant note clusters completely obliterates tonality. At figure 4 for example, the sound cluster that we hear contains seven different notes: four white notes $(C-D-E-F)$ and three black notes $(G b$ $-\mathrm{A}_{b}-\mathrm{B} b$ ). Played fortissimo this creates a dramatic effect. Surprisingly, we have not lost all sense of tonal direction and the repeated pitch interval of $\mathrm{C}$ and $\mathrm{G}$, as well as the repeated pitch $\mathrm{C}$ on cellos and double basses, provides another example of Prokofiev's use of the 'pseudo-tonic'.

\section{Seven, They Are Seven}

Seven, They Are Seven shares thematic concerns with Ala and Lolli. Both are concerned with describing and exploring the conflict between natural and supernatural elements. The notion of impending apocalyptic doom is present in the cantata in a more forceful way than it is in the ballet; nonetheless, both outline the personality of evil in musical terms. Prokofiev's cantata for tenor, chorus and orchestra is based on Konstantin Balmont's poem of the same name. Anthony Phillips notes that the text of the incantation is itself a translation of the original which was written in Old Akkadian, an ancient Semitic language. ${ }^{34}$ When the composer heard Balmont read the poem, it made an immediate impact on him and he wanted to reproduce the effects of Balmont's reading. He was particularly taken by the opening whispers of 'seven, they are seven' as well as the intonation and rhythm of the incantation.

Prokofiev's compositional approach to this work was similar to that of Ala and Lolli - the only difference being that this time it was the text rather than the scenario which suggested particular images and soundscapes. In both cases, imagery was the composer's musical starting point. Having decided on the effects he wanted to achieve and the images he wanted to convey, Prokofiev thought next of the 'textures and figures' in the music (see Figure 1), filling his sketches with his harmonies, and only finishing the orchestration after a slow process that he found very difficult and which, as he himself notes in his Diaries, 'tested to the limits all my powers. ${ }^{35}$

\footnotetext{
${ }^{33}$ Even within the context of fleeting tonalities, Prokofiev manages to create the distinctly solid presence suggested by the tonic chord's sound. The 'pseudo-tonic' is thus a chord which is used as a surrogate for the tonic chord and to all intents and purposes it functions like a tonic chord except for its pitch make-up.

${ }^{34}$ Diaries, Vol. 2 p. 222, footnote 2. Prokofiev himself adds several lines of text to the Balmont incantation.

35 Diaries, Vol. 2, p. 240
} 


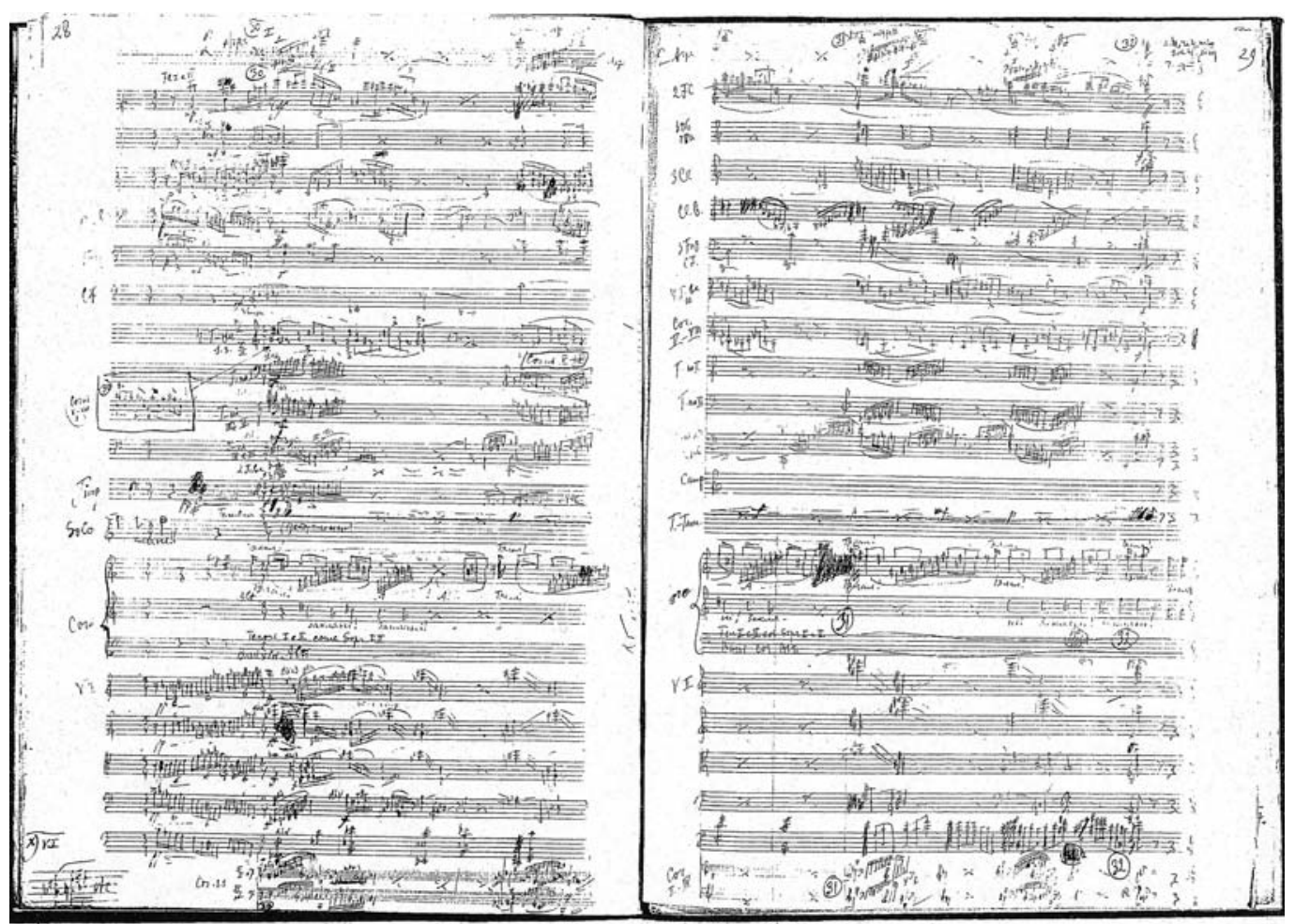

Figure 1:

A double page from Prokofiev's manuscript draft of Seven, They Are Seven
In Seven, They Are Seven Prokofiev makes use, as he does with Scythian Suite, of a large orchestra with an enhanced brass section containing eight horns. The work is written for dramatic tenor and chorus and is scored for maximal effect. The voices are strained to their utmost, causing the American critic Olin Downes to exclaim in dismay, at the première of the work seven years later, that the strain on the tenor in this work was 'really frightful' and that he was required 'to intone his lines in a manner sometimes verging on speech, or yells, instead of song'. According to Downes, the work is both 'violent but undeniably effective $[\ldots]$ horrible and primitive'. ${ }^{36}$ The opening is harsh: it starts forte and continues into a deafening crescendo as the opening progresses. The use of glissandos on horns and two harps, the semitone trill on trumpets, the accented sustained notes on tubas and trombones and the drum roll on the tenor drum make for a particularly impressive and noisy opening. The opening sound image is a dramatic one and it will reverberate throughout the entire work.

Because it is an incantation, this piece provides Prokofiev with the opportunity to work with one of the most important and ubiquitous gestures in his vocabulary - that of the repeated note. He uses it to invoke the effect of an incantation and it becomes the work's unifying gesture. The tenor's first intonation of 'semero ikh' is accompanied by lower registers: double bass, bassoons, double bassoon, tubas, timpani and bass drum. In such incantational passages Prokofiev works with the most economical of means in order to allow the text its full effect. The incantation is built on repetition while the triplet rhythms and high singing register (for the tenor) add to the frenzy of the music. The voice- 
lines have a restricted range, delimited by the tritone: this is another Prokofievan strategy that figures in the vocal lines of The Gambler and Love for Three Oranges for example.

A hysterical and frenzied atmosphere, which prefigures the possession scene in The Fiery Angel, is created through the use of scalar figurations in higher woodwinds and strings. Continuous harp glissandos emphasize the almost sinister magical quality of the piece. The hysteric mood is further enhanced by the soprano and alto lines, which loudly outline the semitone shift (F" to E") in high registers to a doubledotted rhythm. In a typically Prokofievan strategy, the words 'conjure them' are sung as rapid scales by the entire choir: the use of quick scalar figurations (particularly in voice parts) is often associated with the supernatural or with the promise of magic. This technique occurs in both in The Love for Three Oranges and The Fiery Angel. High-pitched trills on woodwind and tremolos on the violins and violas make for a frightening atmosphere. This is an aural image that Prokofiev will come back to time and again in his operas. Already in this work however, he is creating a network of musical gestures and sound combinations that will come to define a particular thematic idea.

\section{Prokofiev's understanding of the modernist aesthetic}

Did Prokofiev consider himself a modernist composer? Elena Poldiaeva suggests that 'Prokofiev first experienced the "demands of modernity" when Diaghilev rejected the ballet Ala and Lolli, and did not accept Chout straightaway. ${ }^{37}$ Certainly it seemed that Prokofiev had difficulty understanding what Diaghilev required from him for Ala and Lolli and the fact that he masked his incomprehension only led to further misunderstanding. He was also demonstrably affected by the criticism of his friend, the musicologist, philosopher and historian Pierre Souvchinsky who did not consider his music modern enough and who noted that his passion for Balmont's verses constituted a refusal to be modern. Prokofiev wryly noted that 'when I am told that The Fiery Angel and Seven, They Are Seven, is a refusal to acknowledge "modernity" then my answer is that I don't understand what you're saying and we'd better go to the doctor, as one of us has atrophy of some very important brain cell! ${ }^{38}$

That Prokofiev is uncomfortable with the term modernity, however, is clear because throughout the letter, he places it in inverted commas. Press notes that during Prokofiev's Diaghilev phase, the composer 'still sought success in Paris [...] and was not above being a modernist composer in French terms, that is, a willingness to astonish at all costs, usually by means of dissonance and decibels. ${ }^{39}$ This type of 'modernism' was also something he had already achieved in his piano works. Poldiaeva notes that for Prokofiev 'modernity' is 'generally a word of opprobrium which may stand for anything but never for the responsibility of the artist to his own age'. ${ }^{40}$ Prokofiev's main responsibility was always to his own artistic aesthetic and he tried to protect himself from any influence which might 'contaminate' his individuality. He had no interest in establishing his own musical system or in following that of others. Minturn is right to note that Prokofiev 'has spawned no clear-

\footnotetext{
37 Elena Poldiaeva, 'Story of a disagreement between Serge Prokofiev and Pierre Souvchinsky', Three Oranges Vol. 3, May 2002, p. 27.

38 Ibid., p. 28.

${ }^{39}$ Stephen D. Press, Prokofiev's Ballets for Diaghilev (Aldershot, England: Ashgate, 2006), p. 65

${ }^{40}$ Elena Poldiaeva, 'Story of a disagreement between Serge Prokofiev and Pierre Souvchinsky', Three Oranges Vol. 3, May 2002, p. 29
} 
cut isms (such as impressionism, or serialism, or primitivism)' ${ }^{41}$ His one governing principle, despite the aesthetic challenges he faced after his return to the Soviet Union, was to be original at all times and to be different. To him, this meant that he was a 'student of my own ideas'.

Even when he was surrounded by the creativity and intellectual flair and imagination of inter-war Paris, Prokofiev remained strangely aloof from contemporary discussions of modernism. Indeed he confesses to Souvchinsky that he finds Stravinsky's aesthetic difficult to understand:

When I played through for him [Stravinsky] my Visions fugitives (pieces which for me are all more or less of equal worth), he was enraptured by one, disgusted by another, and expressing himself so emphatically that at around the tenth Vision, before the beginning of each piece, I began to wonder what he was going to say; and I could never anticipate what was in his head. As for his and Diaghilev's attacks ... what's it all about? Both say that they love my music, and how sincerity isn't so important; what's important is that they say it with such aggressive insistence ...When they yell, sometimes for two hours at a time, I understand nothing, I snap back, so as to add fuel to the fire, I take delight in the scene from the point of view of its picturesqueness, but within my head is aching - what sort of spring is unwinding inside them, why is there so much energy in this spring and where is this spring aiming? ${ }^{42}$

Clearly, Prokofiev had a very specific understanding of modernism as it could be applied to music. For him it meant radicalizing his compositional techniques; expanding his musical language by playing with the boundaries of traditional harmony and sound combinations; distorting established forms in order to accommodate his musical ideas; using shock tactics to draw in his audiences and to sustain the listener's attention. It meant working with texts, librettos and scenarios that were both dramatic (sometimes even melodramatic) and theatrical. His writing also challenges traditional pianistic, vocal and instrumental technique.

Prokofiev eventually despaired of ever understanding the modernist aesthetic as it was perceived by his peers and he gradually began to feel alienated from the new trends that the Parisian public continually demanded. Diaghilev's inconsistent attitude toward Prokofiev's work only served to confuse the composer more: he could not understand or even sympathize with the continually changing trends of the day. For Prokofiev, then, modernism was a contemporary aesthetic of the times he was living in. He participated in it only inasmuch as he could accommodate it to his own ideals. Eventually, the fluid aesthetics of modernism as professed by fellow composers continued to trouble Prokofiev and led to a sustained feeling of isolation from the European avant-garde movement: this alienation became a contributing factor to his return to the Soviet Union.

\footnotetext{
${ }^{41}$ Neil Minturn, The Music of Sergei Prokofiev (New Haven: Yale University Press, 1997), p. 207. Prokofiev's impact may not have led to the establishment of a specific musical 'school' or 'method' but his influence on an entire generation of upcoming composers was nonetheless significant.

${ }^{42}$ Cited in David Nice, Prokofiev: from Russia to the West 1891-1935 (New Haven and London: Yale University Press), p. 201
} 